\title{
DEFİTİNİZE EDİLMİŞ TAHIL KEPEKLERİNİN VE ENZİMLERİN MAKARNANIN FİZIKSEL VE DUYUSAL KALİTESİ ÜZERİNE ETKİLERİ
}

\author{
Hacer Levent ${ }^{* 1}$, Mehmet Koyuncu ${ }^{2}$, Nermin Bilgiçli ${ }^{3}$, \\ Emre Adı̈üzel ${ }^{1}$, Mustafa Dedeoğlu ${ }^{2}$ \\ ${ }^{1}$ Karamanoğlu Mehmetbey Üniversitesi, Sağlık Bilimleri Fakültesi, Beslenme ve Diyetetik Bölümü, Karaman, \\ Türkiye \\ ${ }^{2}$ Karamanoğlu Mehmetbey Üniversitesi, Mühendislik Fakültesi, Gıda Mühendisliği Bölümü, Karaman, Türkiye \\ ${ }^{3}$ Necmettin Erbakan Üniversitesi, Mühendislik ve Mimarlık Fakültesi, Gida Mühendisliği Bölümü, Konya, \\ Türkiye
}

Geliş / Received: 04.11.2019; Kabul / Accepted: 09.03.2020; Online bask1 / Published online: 06.04.2020

Levent, H., Koyuncu, M., Bilgiçli, N, Adıgüzel, E., Dedeoğlu, M. (2020). Defitinize edilmiş tahıl kepeklerinin ve enzimlerin makarnanın fiziksel ve duyusal kalitesi üzerine etkileri. GIDA (2020) 45(2) 397-407 doi: 10.15237/gida.GD19140.

Levent, H., Koyuncu, M., Bilgiçli, N, Adrgürel, E., Dedeoğlu, M. (2020). Effects of depybtinized cereal brans and ensymes on physical and sensory quality of pasta. GID A (2020) 45(2) 397407 doi: 10.15237/gida.GD19140.

\section{ÖZ}

Bu araştırmada, tahıl kepekleri (pirinç, çavdar, buğday ve yulaf) iki farklı yöntemle (fitaz enzimi ve malt unu) defitinize edilmiş ve farklı enzim uygulamaları (ksilanaz ve transglutaminaz) ile makarna formülasyonunda (\% 20 oranında) kullanılmıştır. Tahıl kepekleri makarnanın parlaklık değerlerini kontrol örneklerine kıyasla düşürmüştür $(P<0.05)$. Makarna örneklerinde transglutaminaz + ksilanaz enzimi uygulanarak en yüksek ağırllk, hacim artışı ve en düşük pişirme kaybı değerleri elde edilmiştir. Tahıl kepeği kullanımı, makarna örneklerinde sıkılık değerini azaltmıştır. Duyusal analiz sonuçlarına göre, pirinç kepeği içeren makarna numuneleri diğer çeşitlere göre daha düşük görünüss ve tat puanlarını almışır. Panelistler tarafından yulaf ve buğday kepekli makarna örnekleri daha fazla beğenilmiştir.

Anahtar kelimeler: Makarna, defitinizasyon, kepek, tahıl, enzim

\section{EFFECTS OF DEPYHTINIZED CEREAL BRANS AND ENZYMES ON PHYSICAL AND SENSORY QUALITY OF PASTA}

\begin{abstract}
In this research, cereal brans (rice, rye, wheat and oat) were depyhtinized by two different methods (phytase enzyme and malt flour) and used in pasta formulation (at $20 \%$ level) with different enzyme applications (xylanase and transglutaminase). Cereal brans decreased the brightness value of pasta compared to the control samples $(P<0.05)$. The highest weight, volume increase and the lowest cooking loss values were obtained by the application of transglutaminase+xylanase enzyme in pasta samples. The use of cereal bran decreased firmness value of pasta samples. According to the sensory analysis results, pasta samples containing rice bran had lower appearance and taste scores than other varieties. Oat and wheat bran pasta samples were more appreciated by the panelists.
\end{abstract}

Keywords: Pasta, dephytinization, bran, cereal, enzyme

\footnotetext{
*Yazışmalardan sorumlu yazar / Corresponding author

17: hacerlevent@hotmail.com, (D) (+90) 3382262131

国: (+90) 3382262134
}

Hacer Levent; ORCID no: 0000-0002-7321-5577

Mehmet Koyuncu; ORCID no: 0000-0002-7704-9529

Nermin Bilgiçli; ORCID no: 0000-0001-5490-9824

Emre Adıgüzel; ORCID no: 0000-0002-9041-8990

Mustafa Dedeoğlu; ORCID no: 0000-0001-7866-5350 


\section{GİRIŞ}

Makarna, tahıl ürünleri içerisinde çok eskiden beri bilinen ve dünyada en yaygın olarak tüketilen gıdalardan birisidir (Elgün vd. 2007). Uzun süre muhafaza edilebilirliği, çeşitliliği, doyuruculuğu, kolay pişirilebiliyor olması, besinsel kalitesi ve diğer pek çok gida maddesinden ucuz olması tahıl ürünleri içerisinde makarnayı öne çıkarmaktadır (Yeyinli, 2006). Ülkemizde, kisa kesme makarnalar, spagetti, tel şehriye, arpa şehriye ve kuskus en çok üretimi yapilan makarna çeşitlerinden olup, bunlar çeşitli katkılar kullanılarak zenginleştirilebilmektedir (Elgün ve Ertugay, 1995).

Kepek tanenin aleron ve perikarptan oluşan diş tabakası olup tanenin ögütülmesi ve rafine edilmesi sırasında taneden uzaklaştırılır (Elgün ve Ertugay, 1995; Patel, 2015). Buğday, pirinç, yulaf, çavdar, arpa ve misırdan elde edilen ve genellikle hayvan yemi olarak değerlendirilen tahıl kepekleri, nişasta olmayan karbonhidratlar (arabinoksilan, $\beta$ glucan), fenolik asitler (ferulik asit), flavonoidler (antosiyanin), yă $(\gamma$-orizanol), vitaminler (karotenoidler, tokoller), oligosakkaritler, folatlar ve steroller için depo olarak kabul edilir. Tahıl kepekleri özellikle içerdiği zengin besinsel lif ve fenolik fitokimyasallar ile birçok săglık avantajlarına sahip olup fonksiyonel olarak önemli bir katk1 maddesidir (Patel, 2015).

Yapılan bir çalışmada, infrared yöntemi ile stabilize edilmiş pirinç kepeği erişte formülasyonunda $\% 10-30$ oranında kullanılmış ve eriştenin tekstürel, duyusal ve besinsel özellikleri incelenmiştir (Yılmaz Tuncel vd., 2017). Erişte örneklerinde artan pirinç kepeği oranlarında ham yağ, protein, besinsel lif, B vitaminleri ve mineral madde içeriğinde de artşs olduğu, ortalama pişme süresinin uzadığı bildirilmiştir. Aynı çalışmada, pirinç kepeği ilavesinin eriştenin sertlik değeri üzerine istatistiki olarak önemli bir etkisinin olmadığı ve \%10 ilave oranından sonra duyusal özelliklerin olumsuz etkilendiği belirlenmiştir.

Ertaş (2014), pirinç kepeğini \%25 oranına kadar erişte formülasyonunda kullanmış ve pirinç kepeği kullanımı ile erişte örneklerinin ağırlık ve hacim artış1 değerlerinin yükseldiğini ve duyusal analizlerde $\% 10$ oranında pirinç kepeği içeren örneklerin kontrolden sonra en çok beğenilen örnekler olduğunu bildirmiştir.

Kaur vd. (2012) ise çeşitli tahıl kepekleri (buğday, pirinç, arpa ve yulaf kepeği) ile zenginleştirilmiş makarnaların fonksiyonel özelliklerini inceledikleri çalışmalarında, kepek ilavesi ile makarna örneklerinin su absorbsiyonu ve pişme kayıplarında artış olduğunu belirlemiştir. Ayrıca çeşide bağlı olarak tahıl kepeklerinin \%10-15 oranına kadar kullanılabileceğini bildirmişlerdir.

Tahıl kepekleri, fonksiyonel ve birçok sağlık avantajlarına sahip olmasına rağmen önemli miktarda fitik asit içermektedir. Bu özelliği tahıl kepeklerinin gıda formülasyonunda kullanımını sinırlandırmaktadır. Fitik asit myo-inositol 1,2,3,4,5,6-hexakis (dihidrojen fosfat) hububat, baklagil ve yağlı tohumlarda doğal bir bileşen olarak bulunmaktadır. Fitik asit insan beslenmesinde gerekli olan minerallerle kompleks olusturarak bunların emilimini engellemektedir. Bunun yanı sıra, fitik asitin minerallerle birleşmesiyle olusan fitatlar, protein emilimini de olumsuz yönde etkilemektedir (Bilgiçli, 2002). Fitik asit antibesinsel bir bileşik olduğu düşünülmekte ve gıdalardaki fitat miktarını farklı yöntemlerle azaltmak için büyük çaba gösterilmektedir (Bilgiçli vd., 2006; Kumar vd., 2010).

Gıdalarda fitik asit miktarının azaltılmasında, ögütme, fermantasyon, basınç altında pişirme, çimlendirme, suda bekletme ve fitaz enzimi kullanımı gibi fiziksel, kimyasal ve biyokimyasal metotlar uygulanabilmektedir. Ürünlerin özelliklerine ve üretim sürecine bağlı olarak, birkaç farklı yöntem bir arada da kullanilabilmektedir (Egounlety ve Aworh, 2003; Özkaya vd. 2017; Ertaş, 2018).

Transglutaminaz enzimi, proteinler arasında disülfit olmayan kovalent çapraz bağlar oluşturur ve böylece gluten proteinleri yapısını güçlendirir (Basman vd., 2002; Bellido ve Hatcher, 2010). Wang vd. (2011), transglutaminaz enzimini vital gluten veya yumurta albumini içeren yulaf unundan hazırlanan makarnada kullanmış ve transglutaminaz enziminin makarnada elastikiyeti 
artırdığını, pişirme kaybını ise azalttığını rapor etmiştir. Bellido ve Hatcher (2011) yaptıkları çalışmada, eriştelerde transglutaminaz uygulamasının protein ağını polimerize ettiğini, sertliği ve elastikiyeti artırdığını bildirmişlerdir.

Ksilanaz, yaygın olarak hemiselülaz olarak adlandırılır, hamur işlenebilirliğini ve stabilitesini arttıran ve son ürün kalite özelliklerini geliştiren bir enzimdir ( $\mathrm{Si}$ ve Drost-Lustenberger, 2002). Jyotsna vd. (2004) tel şehriye üretiminde ksilanaz, gluten, askorbik asit, gliserol monostearat, SSL (Sodium stearoyl-2-lactylate) ve glukoz oksidaz kullanmışlar ve ürün kalitesine etkilerini incelemişlerlerdir. Ksilanazın (\%0.012) pişmiş üründeki ağırlık artış1, hacim artışı özelliklerini geliştirdiğini, üründe yapışkanlığı önlediğini, sert dokulu olmasını sağladığını bildirmişlerdir. Susanna ve Prabhasankar (2015) yaptıkları çalışmada, glutensiz makarna üretiminde ksilanaz enziminin pişme kaybı değerinde azalmaya neden olduğunu rapor etmişlerdir.

$\mathrm{Bu}$ araşturmada farklı yöntemlerle defitinize edilmiş tahil kepekleri (pirinç, çavdar, buğday ve yulaf), farklı enzimler (ksilanaz, transglutaminaz, ksilanaz + transglutaminaz) kullanilarak besinsel ve fonksiyonel özellikleri arttırılmış ve teknolojik olarak üstün makarna örnekleri hazırlanmıştır. Elde edilmiş makarna örneklerinin fiziksel, tekstürel, pişme ve duyusal özellikleri incelenmiştir.

\section{MATERYAL VE YÖNTEM}

$\mathrm{Bu}$ araştırmada kullanılan buğday unu ve buğday irmiği Karaman ilinde faaliyet gösteren Golda Gıda San. A.Ş.'den temin edilmiştir. Malt unu İreks Gıda A.Ş.'den, pirinç kepeği Başhan Tarımsal Ürünler A.Ş.'den (Balıkesir), çavdar, buğday ve yulaf kepeği ise Sağlik Tarım Ürünleri'nden (Konya) temin edilmiştir. Vital gluten, Sinerji Gıda Kimya Tekstil San. ve Tic. A.S., ksilanaz ve fitaz enzimleri Orba Biokimya San. ve Tic. A.Ş., transglutaminaz enzimi ise FMI Gıda ve Kimya'dan sağlanmıştır.

\section{Tahıl kepeklerinin defitinizasyon işlemi}

Makarna üretiminde kullanilan tahıl kepekleri (pirinç, çavdar, buğday ve yulaf) partikül iriliği 0.5 mm'nin altında olacak şekilde öğütülmüştür. Daha sonra 2:16 (w/v) oraninda saf su ile karıştrilıp 2 gruba ayrilmıs, birinci gruba $\% 0.5$ $(\mathrm{w} / \mathrm{w})$ fitaz enzimi, ikinci gruba ise $\% 5$ oraninda $(\mathrm{w} / \mathrm{w})$ malt unu ilave edilerek $\mathrm{pH}$, asetik asit ile 5.0 'a ayarlanmış ve $55^{\circ} \mathrm{C}$ 'de 6 saat bekletilmiştir. Bekletme süresi sonunda $250 \mu$ elek üzerinde karışım süzülmüş, $500 \mathrm{ml}$ su ile $1 \mathrm{kez}$ durulanmış ve $60{ }^{\circ} \mathrm{C}$ 'de $\max \% 10$ su içeriğine kadar kurutulmuştur (Pandey vd. 2001; Servi vd. 2008).

\section{Makarna örneklerinin hazırlanması}

Makarna örnekleri Ajila vd. (2010) tarafindan belirtilen metot modifiye edilerek, yaklaşık 100:30 buğday irmiği/su oranı kullanılarak hazırlanmıştır. Makarna formülasyonlarında tahıl kepekleri buğday irmiği ile yer değiştirme esasına göre \%20, ksilanaz ve transglutaminaz enzimleri ise Çizelge 1'de verilen oranlarda makarna üretiminde kullanılmıştır. Şahit makarna, \%100 buğday irmiği ile üretilmiştir. Tahıl kepekli makarna örneklerinde kullanılan su miktarı ön denemeler ile belirlenmiştir. Makarna üretimi için pilot makarna üretim makinesi kullanılmış (La Monferrina, Dolly, İtalya) ve kisa kesme makarna şekli (penne) tercih edilmiştir. Makarna bileşenleri (1500 g buğday irmiği $+\sim 500 \mathrm{ml} \mathrm{su}$ ), irmiğin su hidrasyonu sağlanana kadar pilot makarna ünitesinin yoğurucu kısmında karışturılmış ve hamur $15 \mathrm{dk}$ oda sicaklı̆̆ında, $30 \mathrm{dk}$ ise $30{ }^{\circ} \mathrm{C}$ 'de bekletilip daha sonra ekstrüde edilmiş ve penne kalıbı kullanılarak kesilmiştir. Kurutulan makarna örnekleri polietilen ambalajlar içinde oda koşullarında muhafaza edilmiştir.

\section{Renk ölçümleri}

Hammaddeler ve üretilen bütün makarna örneklerinde renk değerleri Minolta CR-400 (Konica Minolta, Inc., Osaka, Japonya) cihaz1 kullanılarak belirlenmiştir. L* (parlaklık), $a^{*}$ (kırmızı, yeşil) ve $b^{*}$ (sarı, mavi) değerleri saptanmıştur. C* (doygunluk indeksi) değeri ise $\left(a^{* 2}+b^{* 2}\right)^{1 / 2}$, Hue (renk özü) değeri $\arctan \left(b^{*} / a^{*}\right)$ formülü ile hesaplanmıştır (Francis, 1998).

Makarnada ağırlık, hacim artışı ve pişme kaybının belirlenmesi

Ağırlık artışının belirlenmesi için 20 gr makarna, $250 \mathrm{ml}$ kaynayan saf su içerisinde optimum pişme 
süresince pişirilmiş, çiğ ve pişmiş örneklerdeki ağırlık fark1 \% olarak belirlenmiştir. Hacim artışının belirlenmesi için örnekler aynı ağırlık artış1 testinde olduğu gibi pişirilip süzülmüş ve 2 $\mathrm{dk}$. bekletildikten sonra içerisinde saf su bulunan ölçü silindirine koyulup taşırdıkları suyun hacmi belirlenmiştir. $\mathrm{Bu}$ değerlerden hacim artış1 değerleri hesaplanmıştır (Oh vd., 1985; Özkaya ve Kahveci, 1990). Pişme kaybı için, makarnaların pişme suyu kurutma dolabında $135{ }^{\circ} \mathrm{C}$ 'de kurutularak, pişme kaybı miktarı (\%) hesaplanmıştır (Özkaya ve Kahveci, 1990).

Çizelge 1. Makarna üretiminde kullanılan deneme deseni

Table 1. The trial pattern used in pasta production

\begin{tabular}{|c|c|c|}
\hline Kepek çeşidi/Bran type & $\begin{array}{l}\text { Defitizasyon metodu } \\
\text { /Dephytinization method }\end{array}$ & Enzim uygulamas1/Enzyme application \\
\hline \multirow{8}{*}{$\begin{array}{l}\text { Pirinç kepeği/Rice bran } \\
\text { Çavdar kepeği/ Rye bran } \\
\text { Buğday kepeği/ Wheat bran } \\
\text { Yulaf kepeği/Oat bran }\end{array}$} & \multirow{4}{*}{ Fitaz enzimi/Phytase enzyme } & Enzim uygulamasiz / without enzme \\
\hline & & Ksilanaz / Xylanase $(\% 0.01)$ \\
\hline & & $\begin{array}{l}\text { Transglutaminaz/Transglutaminase } \\
(\% 0.5)\end{array}$ \\
\hline & & $\begin{array}{l}\text { Ksilanaz/ Xylanase } \\
(\% 0.01)+\text { Transglutaminaz/ } \\
\text { Transglutaminase }(\% 0.5)\end{array}$ \\
\hline & \multirow{4}{*}{ Malt unu/Malt flour } & Enzim uygulamasiz / without enzme \\
\hline & & Ksilanaz / Xylanase $(\% 0.01)$ \\
\hline & & $\begin{array}{l}\text { Transglutaminaz/Transglutaminase } \\
(\% 0.5)\end{array}$ \\
\hline & & $\begin{array}{l}\text { Ksilanaz/ Xylanase } \\
(\% 0.01)+\text { Transglutaminaz/ } \\
\text { Transglutaminase }(\% 0.5)\end{array}$ \\
\hline
\end{tabular}

Deneme, 4 (kepek çeşidi), 2 (defitinizasyon metodu), 4 (enzim uygulaması) ile (4x2x4)x2 faktöriyel deneme desenine uygun olarak 2 tekerrürlü olarak yürütülmüştür.

The experiment was carried out in duplicate in accordance with the 4 (bran type), 2 (dephytinization method), 4 (ensyme application) and $(4 \times 2 \times 4) \times 2$ factorial trial pattern.

\section{Makarnada sık1lık değerinin belirlenmesi}

Defitinize edilen tahil kepekleri ile üretilen makarna örneklerinde, renk, pişme analizi ve fitik asit sonuçlarına göre, besinsel (fitik asit miktarı en az, sonuçlar gösterilmemiştir) ve teknolojik olarak üstün (pişme testleri) makarna örnekleri belirlenmiştir. Fitaz enzimi ile defitinize edilmiş tahıl kepekleri içeren, ksilanaz+transglutaminaz ile muamele edilen makarna örnekleri sikılık ölçümlerinde kullanılmıştır. Sıkılık değeri, TAXT Plus Texture Analyzer (Stable Microsystems, Surrey, UK) kullanılarak pişirilmiş makarna örneklerinde ölçülmüsstür. Analiz için A/LKB-F bıçak donanımı kullanılmıştır.

\section{Duyusal analizler}

Besinsel ve teknolojik olarak üstün makarna örneklerinde duyusal analiz yapılmışır. Makarna örneklerinin duyusal özellikleri, 22 panelist (25-55 yaş) tarafindan belirlenmiştir. Panelistlerden, makarna örneklerini renk, görünüş, sertlik, yapışkanlık, tat, koku ve genel beğeni açısından değerlendirmeleri istenmiştir. Duyusal özelliklerin değerlendirilmesinde 1-7 arasındaki skala (1:aşırı kötü, 2:çok kötü, 3:kötü, 4:orta, 5:iyi, 6:çok iyi ve 7:mükemmel) kullanılmışır (Epler vd., 1998).

\section{İstatistiksel analizler}

İstatistiki analizlerde JMP istatistik program1, 10.0 versiyonu (SAS Institute Inc., Cary, NC, ABD) kullanılmıştır. Elde edilen veriler varyans analizine tabi tutulmuş, ana varyasyon kaynaklarının ortalamaları karşılaştırılmıştır $(P<0.05)$.

\section{BULGULAR VE TARTIŞMA}

Makarna üretiminde kullanilan bazı hammaddelerin ve makarna örneklerinin renk ölçümü sonuçlan Çizelge 2 ve Çizelge 3'de 
verilmiştir. Kepek faktörü açısından değerlendirildiğinde, makarna örneklerinde $L^{*}$ değeri 73.44 ile 81.76 arasında değişmiştir. Buğday irmiği ile hazırlanan kontrol erişte örneğinde $L^{*}$ değeri 87.97 olarak ölçülmüss, tahıl kepekleri kullanımı makarna örneklerinde $L^{*}$ değerinde bir düşüşe neden olmuştur. Kullanilan hammaddelerden tahıl kepeklerinin buğday irmiğinden daha düşük $L^{*}$ değerine sahip olması son ürünün rengi üzerinde etkili olmuş olabilir
(Çizelge 2). Makarna örneklerinde çavdar kepeği en yüksek, yulaf ve pirinç kepekleri ise en düşük kırmızılık değerlerinin elde edilmesini sağlamıştur. Pirinç kepeği makarna örneklerinde en düşük sarılık ve chroma değerinin elde edilmesini sağlamıştır. Yulaf kepekli makarnada ise en yüksek hue değeri elde edilmiştir. Defitinizasyon yöntemi ve enzim uygulaması açısından örneklerin renk değerleri istatistiki olarak birbirinden farklı bulunmamıştur (Çizelge 3).

Çizelge 2. Makarna üretiminde kullanılan bazı hammaddelerin renk analizi sonuçlanı

Table 2. The color analysis results of some raw materials used in pasta production

\begin{tabular}{lccccc}
\hline Hammadde/Raw materials & $\mathrm{L}^{*}$ & $\mathrm{a}^{*}$ & $\mathrm{~b}^{*}$ & $\mathrm{C}^{*}$ & Hue \\
\hline Buğday unu/Wheat flour & $93.52 \pm 0.40 \mathrm{a}$ & $-0.60 \pm 0.11 \mathrm{~d}$ & $10.01 \pm 0.13 \mathrm{e}$ & $10.03 \pm 0.15 \mathrm{e}$ & $93.43 \pm 0.35 \mathrm{a}$ \\
Buğday irmiği/Wheat semolina & $89.09 \pm 0.25 \mathrm{~b}$ & $-1.76 \pm 0.13 \mathrm{e}$ & $21.81 \pm 0.17 \mathrm{~b}$ & $21.88 \pm 0.19 \mathrm{~b}$ & $94.61 \pm 0.42 \mathrm{a}$ \\
Pirinç kepeği/Rice bran & $70.28 \pm 0.24 \mathrm{e}$ & $2.23 \pm 0.07 \mathrm{c}$ & $21.13 \pm 0.13 \mathrm{~b}$ & $21.25 \pm 0.12 \mathrm{~b}$ & $83.98 \pm 0.59 \mathrm{~b}$ \\
Çavdar kepeği/Rye bran & $70.31 \pm 0.30 \mathrm{e}$ & $3.95 \pm 0.11 \mathrm{~b}$ & $16.93 \pm 0.25 \mathrm{~d}$ & $17.38 \pm 0.26 \mathrm{~d}$ & $76.87 \pm 0.35 \mathrm{~d}$ \\
Buğday kepeği/Wheat bran & $72.42 \pm 0.45 \mathrm{~d}$ & $4.46 \pm 0.14 \mathrm{a}$ & $23.46 \pm 0.31 \mathrm{a}$ & $23.88 \pm 0.33 \mathrm{a}$ & $79.24 \pm 0.31 \mathrm{c}$ \\
Yulaf kepeği/Oat bran & $78.45 \pm 0.34 \mathrm{c}$ & $2.22 \pm 0.17 \mathrm{c}$ & $19.20 \pm 0.23 \mathrm{c}$ & $19.33 \pm 0.21 \mathrm{c}$ & $83.40 \pm 0.66 \mathrm{~b}$ \\
\hline
\end{tabular}

Farklı harfle işaretlenmiş ortalamalar istatistiki olarak birbirinden farklıdır $(P<0.05)$.

$V$ alues marked with different letters are statistically different $(P<0.05)$.

Çizelge 3. Makarna örneklerinin renk ölçüm sonuçlarına ait ortalamaların karşılaştırılması Table 3. Comparison of the averages of color measurement results of pasta samples

\begin{tabular}{lcccccc}
\hline & $\mathrm{n}$ & $\mathrm{L}^{*}$ & $\mathrm{a}^{*}$ & $\mathrm{~b}^{*}$ & $\mathrm{C}^{*}$ & Hue \\
\hline Kepek cessidi/Bran type & & & & & & \\
Pirinç/Rice & 16 & $81.76 \mathrm{a}$ & $1.46 \mathrm{c}$ & $14.17 \mathrm{c}$ & $14.25 \mathrm{c}$ & $84.13 \mathrm{~b}$ \\
Çavdar/Rye & 16 & $73.44 \mathrm{~d}$ & $2.94 \mathrm{a}$ & $17.30 \mathrm{~b}$ & $17.55 \mathrm{~b}$ & $79.93 \mathrm{~d}$ \\
Buğday/Wheat & 16 & $76.34 \mathrm{c}$ & $2.50 \mathrm{~b}$ & $18.80 \mathrm{a}$ & $18.98 \mathrm{a}$ & $82.52 \mathrm{c}$ \\
Yulaf/Oat & 16 & $79.23 \mathrm{~b}$ & $1.49 \mathrm{c}$ & $17.91 \mathrm{ab}$ & $17.97 \mathrm{ab}$ & $85.26 \mathrm{a}$ \\
Defitinizasyon yöntemi & & & & & & \\
Dephytinization method & & & & & & \\
Fitaz enzimi/Phytase ensyme & 32 & $77.13 \mathrm{a}$ & $2.14 \mathrm{a}$ & $17.29 \mathrm{a}$ & $17.43 \mathrm{a}$ & $83.08 \mathrm{a}$ \\
Malt unu/Malt flour & 32 & $78.25 \mathrm{a}$ & $2.05 \mathrm{a}$ & $16.81 \mathrm{a}$ & $16.95 \mathrm{a}$ & $82.83 \mathrm{a}$ \\
Enzim uygulaması/Ensyme application & & & & & & \\
EU & 16 & $77.59 \mathrm{a}$ & $2.05 \mathrm{a}$ & $17.12 \mathrm{a}$ & $17.26 \mathrm{a}$ & $83.19 \mathrm{a}$ \\
$\mathrm{K}$ & 16 & $76.92 \mathrm{a}$ & $2.29 \mathrm{a}$ & $17.76 \mathrm{a}$ & $17.93 \mathrm{a}$ & $82.68 \mathrm{a}$ \\
$\mathrm{T}$ & 16 & $78.55 \mathrm{a}$ & $1.95 \mathrm{a}$ & $16.55 \mathrm{a}$ & $16.68 \mathrm{a}$ & $83.19 \mathrm{a}$ \\
$\mathrm{K}+\mathrm{T}$ & 16 & $77.72 \mathrm{a}$ & $2.09 \mathrm{a}$ & $16.76 \mathrm{a}$ & $16.90 \mathrm{a}$ & $82.76 \mathrm{a}$ \\
\hline
\end{tabular}

Farklı harfle işaretlenmiş ortalamalar istatistiki olarak birbirinden farklıdır $(P<0.05)$. (4x2x4)x2 faktöriyel dizayn, EU:Enzim uygulanmamış; K:Ksilanaz; T:Transglutaminaz

Values marked with different letters are statistically different $(P<0.05)$. (4×2×4) $\times 2$ factorial design, EU: Ensyme not applied; K: Xylanase; T: Transglutaminase 
Makarna örneklerinin pişirme testi sonuçları Çizelge 4'de verilmiştir. Makarna örneklerinde ağırlık ve hacim artışı değerleri kepek çeşidine bağlı olarak sirasiyla \%171.78 ile \%179.01 ve $\% 252.23$ ile \%270.14 arasında değişmiştir. Kontrol makarna örneğinde ise ağıllık ve hacim artışı değerleri sırasılyla $\% 160.85$ ve $\% 236.40$ olarak bulunmuştur. Tahıl kepekleri içeren makarna örneklerinin ağırlık ve hacim artışı değerleri kontrol örneğinden yüksek bulunmuştur. Makarna çeşitleri içinde en yüksek ağıllık ve hacim artışı buğday kepekli makarnada belirlenmiştir. Buğday kepekli makarna haricindeki diğer çeşitlerin ağırlık artışı değerleri birbirinden istatistiki olarak farklı bulunmamıştır. Makarna çeşitleri arasında en düşük hacim artış1 değeri, çavdar kepekli makarnada bulunmuştur. Makarna örneklerinde ağırlık ve hacim artşs değerleri üzerinde defitinizasyon yöntemlerinden fitaz enzimi ve malt unu uygulamasinın etkili olmadığ1 belirlenmiştir. Sonuçlar enzim uygulaması faktörü açısından değerlendirildiğinde ağırlık ve hacim artışı değerlerinin sırasıyla $\% 167.52$ ile $\% 181.14$ ve $\% 250.84$ ile $\% 272.14$ arasında değiştiği görülmüştür. En yüksek ağırlık $(\% 181.14)$ ve hacim artış değerleri (\%272.14) ise ksilanaz+transglutaminaz katk1l örneklerde bulunmuştur. Takács vd. (2007) yaptıkları çalışmada bezelye unu içeren glutensiz eriştelerde transglutaminaz enziminin su absorbsiyonunu arttırdığını bildirmişlerdir. Jyotsna vd. (2004), tel şehriye üretiminde farklı katkıların (ksilanaz, gluten, askorbik asit, gliserol monostearat, SSL (Sodium stearoyl-2-lactylate) ve glukoz oksidaz) ürün kalitesi üzerine etkilerini incelemişler ve ksilanazın (\%0.012 oranında) üründe pişmiş ağıllığ $\operatorname{arttırdığ1~ve~hacim~artış1~sağladığını~}$ belirlemişlerdir.

Çizelge 4. Makarna örneklerinin pişirme testi sonuçlarına ait ortalamaların karşılaştırılması Table 4. Comparison of the averages of cooking test results of pasta samples

\begin{tabular}{|c|c|c|c|c|}
\hline & $\mathrm{n}$ & $\begin{array}{c}\text { Ağırllk artış1 } \\
\text { Weight increase } \\
(\%)\end{array}$ & $\begin{array}{c}\text { Hacim artış1 } \\
\text { Volume increase } \\
(\%)\end{array}$ & $\begin{array}{c}\text { Pişme kayb1 } \\
\text { Cooking loss } \\
(\%)\end{array}$ \\
\hline \multicolumn{5}{|l|}{ Kepek çesidi/ Bran type } \\
\hline Pirinç/Rice & 16 & 171.78b & $259.92 \mathrm{~b}$ & $7.78 \mathrm{a}$ \\
\hline Çavdar/Rye & 16 & $172.19 \mathrm{~b}$ & $252.23 \mathrm{c}$ & $7.83 \mathrm{a}$ \\
\hline Buğday/Wheat & 16 & $179.01 \mathrm{a}$ & $270.14 \mathrm{a}$ & $6.95 b$ \\
\hline Yulaf/Oat & 16 & $174.04 \mathrm{~b}$ & $262.60 \mathrm{~b}$ & $6.54 c$ \\
\hline \multicolumn{5}{|l|}{ Defitinizasyon yöntemi } \\
\hline \multicolumn{5}{|l|}{ Dephytinization method } \\
\hline Fitaz enzimi/Phytase ensyme & 32 & $175.18 \mathrm{a}$ & $261.65 a$ & $7.31 \mathrm{a}$ \\
\hline Malt unu/Malt flour & 32 & $173.33 a$ & $260.80 \mathrm{a}$ & $7.25 \mathrm{a}$ \\
\hline \multicolumn{5}{|c|}{ Enzim uygulamasi/Ensyme application } \\
\hline $\mathrm{EU}^{\circ}$ & 16 & $167.52 \mathrm{~b}$ & $250.84 d$ & $8.01 \mathrm{a}$ \\
\hline K & 16 & $170.08 \mathrm{~b}$ & $257.27 \mathrm{c}$ & $7.20 \mathrm{~b}$ \\
\hline $\mathrm{T}$ & 16 & $178.28 b$ & $264.64 b$ & $7.08 \mathrm{~b}$ \\
\hline $\mathrm{K}+\mathrm{T}$ & 16 & $181.14 \mathrm{a}$ & $272.14 \mathrm{a}$ & $6.80 \mathrm{c}$ \\
\hline
\end{tabular}

Farklı harfle işaretlenmiş ortalamalar istatistiki olarak birbirinden farklıdır $(P<0.05)$. (4x2x4)x2 faktöriyel dizayn, EU:Enzim uygulanmamış; K:Ksilanaz; T:Transglutaminaz

$V$ alues marked with different letters are statistically different $(P<0.05)$. (4×2×4) ×2 factorial design, EU: Ensyme not applied; $K$ : Xylanase; T: Transglutaminase

Kepek çeşidi faktörüne göre, makarna örneklerinde pişme kaybı miktarı \%6.54 ile \%7.83 arasında değişmiştir. Kontrol makarna örneğinde pişme kaybı miktarı \%4.63 bulunmuş, makarna üretiminde tahıl kepekleri kullanımı pişme kaybı miktarının yükselmesine neden olmuştur. Tahıl çeşitleri arasında pirinç kepeği ve çavdar kepeği pişme kaybı değerlerini diğer kepek çeşitlerine göre daha çok arttırarak makarna pişme özellikleri üzerinde olumsuz etkiye sahip olmuşlardır. Makarna örnekleri içinde en düşük pişme kaybı değeri ise yulaf kepekli makarna örneğinde 
belirlenmiştir (\%6.54). Sudha vd. (2011) farklı sıcaklık uygulamalan ile stabilize ettkileri buğday kepeklerini ilave ettikleri makarna örneklerinin tümünde pişme kaybının kontrole kıyasla daha yüksek olduğunu bildirmişlerdir. Pişme kaybı değerleri defitinizasyon yöntemlerine göre birbirinden istatistiki olarak farklı bulunmamıştır.

Enzim uygulanmamış makarna örneklerinde en yüksek pişme kaybı değeri belirlenirken, en düşük pişme kaybı değeri ise genel olarak ksilanaz+ transglutaminaz enzimi uygulamasinda elde edilmiştir (Şekil 1). Transglutaminaz enzimi, deskriptif olarak ksilanaz enziminden daha az pişme kaybına neden olmuş ancak bu fark istatistiki olarak farksız bulunmuştur (Çizelge 4 ve Şekil 1). Yapılan bir çalışmada bezelye unu ve transglutaminaz enziminin glutensiz erişte üretiminde, ürün kalitesi üzerine etkileri değerlendirilmiş ve transglutaminaz enziminin pişme kaybını azalttığı bildirilmiştir (Takács vd. 2007). Yapılan bir başka çalışmada transglutaminaz enziminin buğday esaslı makarna kalitesi üzerine etkileri incelenmiş ve enzim uygulamasının pişme kaybı değerini azalttı̆̆ bildirilmiştir (Takács ve ark, 2008). Rosa-Sibakov vd. (2016), bakla ununu glutensiz makarnada kullanmışlar ve transglutaminaz enzimi ilavesinin, transglutaminaz ilave edilmemiş kombinasyonları ile karşılaştırıldığında bakla unu-transglutaminaz veya nişasta-bakla unu-transglutaminaz makarnalarında pişme kaybı üzerine etkisinin olmadığı rapor edilmiştir. Susanna ve Prabhasankar (2015), glutensiz makarna üretiminde, farklı enzimler (proteaz, transglutaminaz, ksilanaz ve aktinaz) kullanmışlar ve ksilanaz enziminin makarna örneklerinde pişme kaybı değerlerini azalttı̆̆ını belirlemişlerdir.

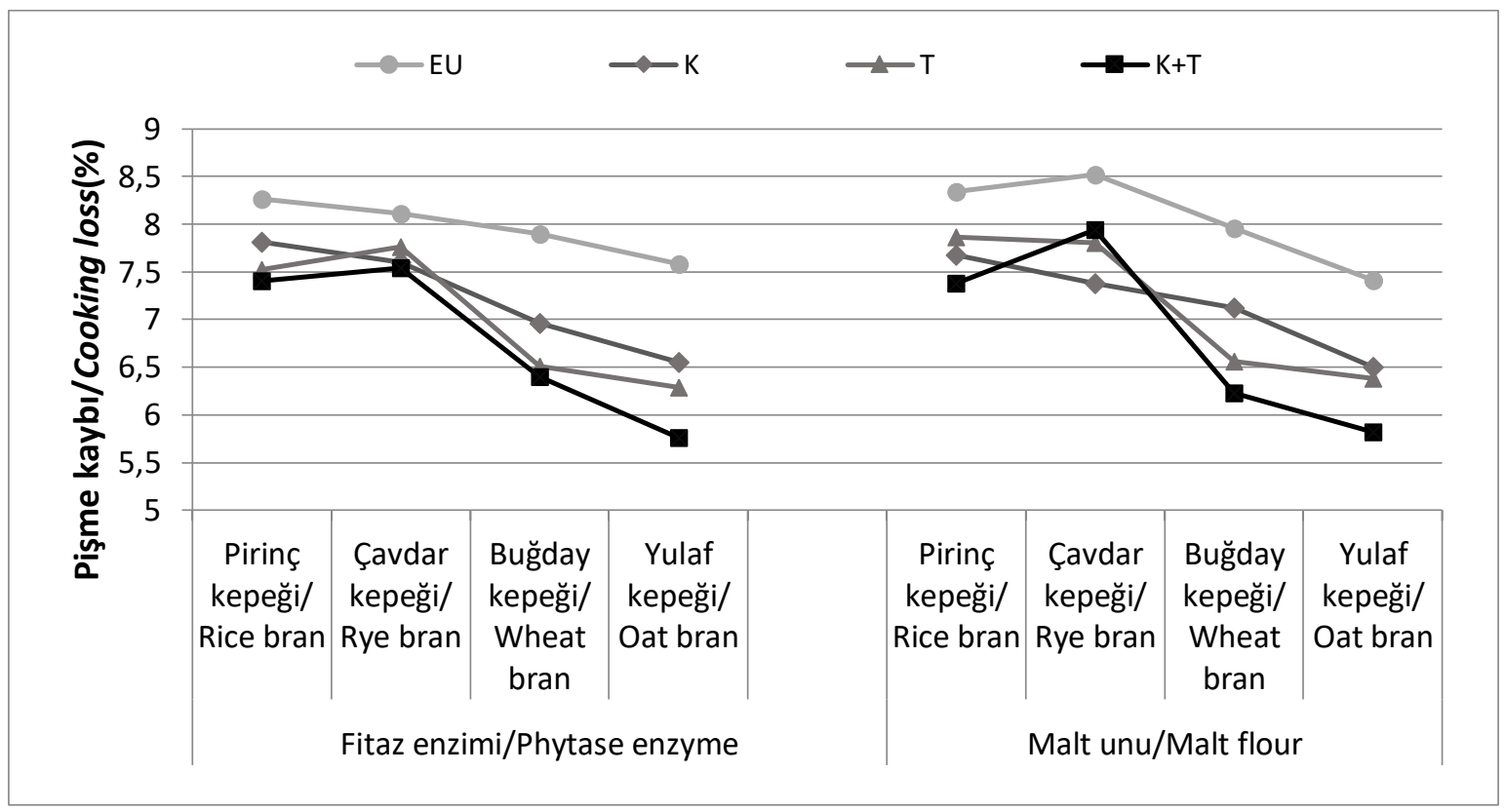

Şekil 1. Makarna örneklerinde pişme kaybı değerleri üzerine etkili "Kepek çeşidi x defitinizasyon yöntemi x enzim uygulaması" interaksiyonu (EU: Enzim uygulanmamış; K:Ksilanaz; T:Transglutaminaz)

Figure 1. "Bran type $x$ dephytinization method $x$ ensyme application" interaction effective on cooking loss values of pasta samples (EU: Ensyme not applied; K: Xylanase; T: Transglutaminase)

Teknolojik olarak üstün fitaz enzimi ile muamele edilmiş ve ksilanaz+transglutaminaz katkılı makarna örneklerinin sıkılık analiz sonuçları Şekil 2'de verilmiştir. Makarna örneklerinde sik1lık değerleri 1109.60-2039.00 g aralı̆̆ında değişim göstermiştir. Makarna örneklerinde tahıl kepekleri kullanımı kontrole kıyasla sıkılık değerlerinin azalmasına neden olmuştur. Susanna ve 
Prabhasankar (2015) glutensiz makarna üretiminde farklı enzimlerin (proteaz, transglutaminaz, ksilanaz ve aktinaz) etkisini incelemişler ve enzim katkilı örneklerin tekstür analizinde, tüm makarna çeşitlerinin kontrol makarna örneğine göre biraz daha düşük sıkılığa sahip olduğunu rapor etmişlerdir. Makarna örneklerinde kontrolden sonra en yüksek s1k1lık değeri çavdar kepekli makarna örneğinde belirlenmiştir. Sudha vd. (2011), farklı sıcaklık uygulamaları ile elde ettikleri buğday kepeği örneklerini makarna üretiminde kullanmışlar, işlem uygulanmış buğday kepeği içeren makarna örneklerinde s1k1lı değerinin 156'dan 113g'a azaldığını, sıkılık değerindeki bu azalmanın buharlı sicak hava uygulamasi ile elde edilen kepekleri içeren makarna örneklerinde daha az olduğunu bildirmişlerdir. Yapılan bir çalışmada makarna formülasyonuna farklı besinsel lif (buğday, arpa ve yulaf lifleri) ve antioksidan kaynakları (keten tohumu, çörek otu ve nar çekirdeği) eklenmiş ve besinsel lif kaynaklarının yüksek oranda kullaniliyor olmasinın gluteni oransal olarak daha fazla seyreltici etkiye sahip olduğu, suya geçen kuru madde ve sıkılık değerlerini olumsuz yönde etkilediği rapor edilmiştir (Madenci, 2017). Rakhesh vd. (2015), spagettide yaptıklar1 çalışmada, aynı ikame oranlarında farklı liflerin makarnanın sıkılık, yapışkanlık, pişme kaybı ve duyusal özellikler üzerine etkilerinin farkl1 olduğunu, bir lif için elde edilen sonuçların diğer lifler için genellenemeyeceğini bildirmişlerdir. Liflerin genel olarak makarnanın sıkılık değerini düşürdüğünü (kepek) ve bu durumun liflerin irmik ile yer değiştirmesi sonucu gluten içeriğinin azalması, nişasta-protein matriksinin zarar görmesi ve daha çok nişastanın şişmesine izin vermesine ve makarnanın yumuşamasına bağlanabildiği rapor edilmiştir. Bununla birlikte aynı çalısmada makarna üretiminde $\beta$ - glukanca zengin un ve polard kullanımının makarna sertliğini artturdığ1 bildirilmiştir. Foschia vd. (2015) ise, tel şehriye üretiminde yulaf kepeği ilavesinin makarnanın sıkılık değerini arttırdığını, yulaf kepeği-inulin karışımının ise düşürdüğünü belirtmişlerdir.

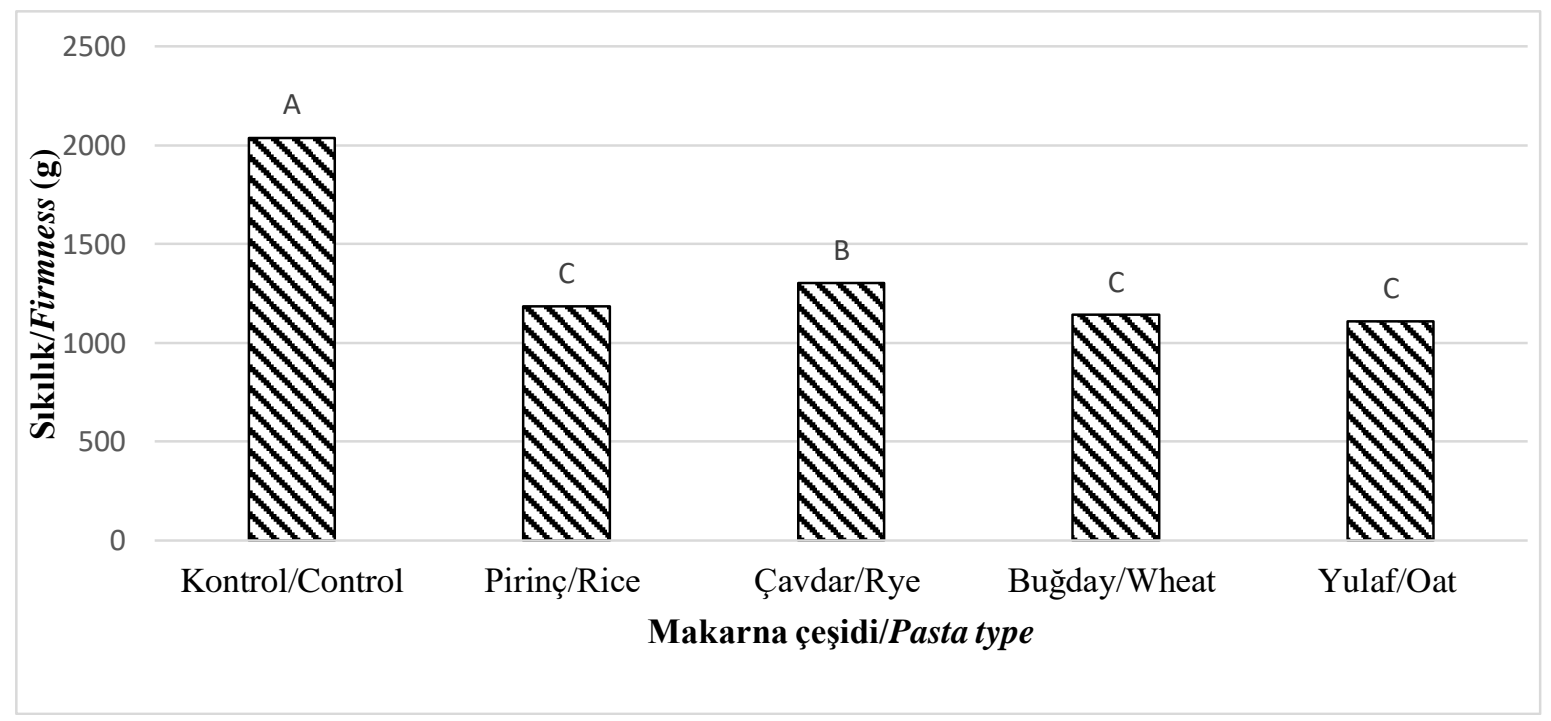

Şekil 2. Teknolojik olarak üstün makarna örneklerinin sıkılık analiz sonuçları Figure 2. Firmness analysis results of technologically superior pasta samples

Teknolojik açıdan üstün bulunan makarna örneklerinin duyusal analiz sonuçları Şekil 3'de verilmiştir. Makarna örneklerinde pirinç kepeği kullanımı görünüş, tat, koku ve genel beğeni puanlarında daha çok azalmaya neden olmuştur. Duyusal analiz sonuçlarına göre makarna üretiminde yulaf kepeği ve buğday kepeğinin kullanımı genel beğeni açısından daha yüksek sonuçlar vermiştir. Bütün tahıl kepekleri makarna üretiminde pişme kaybını kontrol örneğine kıyasla arttırmıştır. Buna rağmen tahıl kepekli makarna örnekleri (çavdar kepekli makarna hariç) 
yapışkanlık açısından kontrolle eşdeğer puan almışlardır. Benzer şekilde Jyotsna vd. (2004), tel şehriye üretiminde farklı katkıların ürün kalitesine olan etkilerini inceledikleri çalışmalarında ksilanaz enziminin (\%0.012) üründe yapışkanlık olmadan kaliteyi geliştirdiğini rapor etmişlerdir.

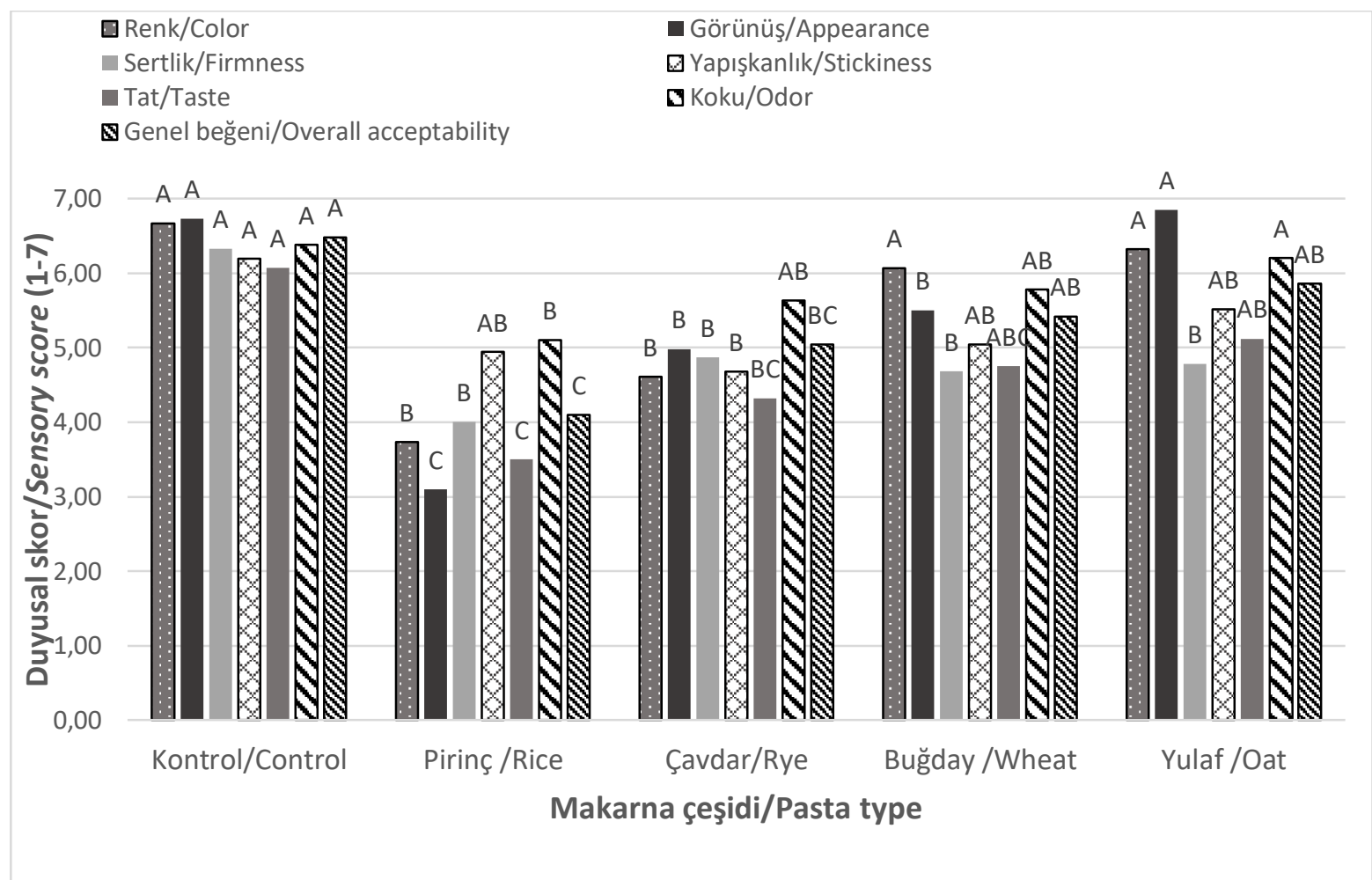

Şekil 3. Makarna örneklerine ait duyusal analiz sonuçları

Figure 3. The sensory analysis results of pasta samples

\section{SONUÇ}

Makarna üretiminde tahıl kepekleri kullanımı kontrol örneğine kiyasla $L^{*}$ değerinde azalmaya ve $a^{*}$ değerinde ise artşsa neden olmuştur. Tahıl kepekleri kullanımı makarna örneklerinde ağırlık ve hacim artış1 değerlerini yükseltmiş, sıkılık değerinde ise azalmaya neden olmuştur. Ksilanaz+transglutaminaz uygulaması daha yüksek ağırlık ve hacim artışı ve daha düşük pişme kayıplarının elde edilmesini sağlamıştır. Genel olarak pirinç kepeği, diğer tahıl kepeklerine kıyasla makarna örneklerinde duyusal analiz puanlarında daha çok azalmaya neden olmuştur. Pirinç kepeği ve çavdar kepeğinin makarna üretiminde $\% 20$ 'den daha düşük oranda kullanılması önerilebilir. Yulaf kepekli ve buğday kepekli makarna, diğer tahıl kepekli makarna çeşitlerine göre daha çok beğenilmiştir.

\section{TEŞEKKÜR}

$\mathrm{Bu}$ çalışma Türkiye Bilimsel ve Teknolojik Araşturma Kurumu (TÜBİTAK) tarafindan 1180385 No’lu proje ile desteklenmiştir.

\section{KAYNAKLAR}

Ajila, C.M., Aalami, M., Leelavathi, K., Rao, U.P. (2010.) Mango peel powder: A potential source of antioxidant and dietary fiber in macaroni preparations. Innovative Food Sci Emerg Technol, 11(1): 219-224, doi: $10.1016 /$ j.ifset.2009.10.004

Başman, A., Köksel, H., Ng, P.K.W. (2002). Effects of transglutaminase on SDS-PAGE patterns of wheat, soy, and barley proteins and their blends. J Food Sci, 67(7): 2654-2658, doi: 10.1111/j.1365-2621.2002.tb08794.x 
Bellido, G.G., Hatcher, D.W. (2010). Ultrasonic characterization of fresh yellow alkaline noodles. Food Res Int, 43(3): 701-708, doi: 10.1016/j.foodres.2009.11.010

Bellido, G.G., Hatcher, D.W. (2011). Effects of a cross-linking enzyme on the protein composition, mechanical properties, and microstructure of Chinese-style noodles. Food Chem, 125(3): 813822, doi: 10.1016/j.foodchem.2010.08.008

Bilgiçli, N. (2002). Fitik asitin beslenme açisindan önemi ve fitik asit miktarı düşürülmüş gıda üretim metotları. Selçuk Tar Bil Derg, 16(30): 79-83.

Bilgiçli, N., Elgün, A., Türker, S. (2006). Effects of various phytase sources on phytic acid content, mineral extractability and protein digestibility of tarhana. Food Chem, 98(2): 329-337, doi: 10.1016/j.foodchem.2005.05.078

Egounlety, M., Aworh, O.C. (2003). Effect of soaking, dehulling, cooking and fermentation with Rhizopus oligosporus on the oligosaccharides, trypsin inhibitor, phytic acid and tannins of soybean (Glycine max Merr.), cowpea (Vigna unguiculata L. Walp) and groundbean (Macrotyloma geocarpa Harms). J Food Eng, 56(23): 249-254, doi: 10.1016/S0260-8774(02)002625

Elgün, A., Ertugay, Z. (1995). Tahıl İsleme Teknolojisi, Atatürk Üniversitesi Ziraat Fakültesi Yayınlar1 No:718, Erzurum, Türkiye, 198 s.

Elgün, A., Türker, S., Bilgiçli, N. (2007). Tahıl Ürünleri Teknolojisi, Selçuk Üniversitesi Gıda Mühendisliği Bölümü, Konya, Türkiye.

Epler, S., Chambers, E., Kemp, K.E., (1998). Hedonic scales are a better predictor than justabout-right scales of optimal sweetness in lemonade. J Sens Stud, 13(2): 191-197, doi: 10.1111/j.1745-459X.1998.tb00082.x

Ertaş, N. (2014). Reutilisation of rice by product: study on the effect of rice bran addition on physical, chemical and sensory properties of erişte. Quality Assurance and Safety of Crops \& Foods, 6(2): 249-255, doi: 10.3920/QAS2013.0252

Ertaş, N. (2018). Effects of baker's yeast addition on some properties and phytic acid content of tarhana prepared with different cereal and legume products. Food and Health, 4(1): 9-18, doi: 10.3153/JFHS18002

Foschia, M., Peressini, D., Sensidoni, A., Brennan, M.A., Brennan, C.S. (2015). How combination of dietary fibers can affect physicochemical characteristics of pasta. LWTFood Science and Technology, 61:41-46, doi: 10.1016/j.lwt.2014.11.010

Francis, F.J. (1998). Colour analysis. In: Food Analysis, Nielsen, S.S. (Ed.). An Aspen Publishers, Maryland, Gaithersnurg, USA, pp. 599-612.

Jyotsna, R., Prabhasankar, P., Indrani, D., Rao, G.V. (2004). Effect of additives on the quality and microstructure of vermicelli made from Triticum aestivum. Eur Food Res Technol, 218(6): 557-562, doi: 10.1007/s00217-004-0887-4

Kaur, G., Sharma, S., Nagi, H.P.S., Dar, B.N., (2012). Functional properties of pasta enriched with variable cereal brans. J Food Technol, 49(4): 467-474, doi: 10.1007/s13197-011-0294-3

Kumar, V., Sinha, A.K., Makkar, H.P., Becker, K. (2010). Dietary roles of phytate and phytase in human nutrition: A review. Food Chem, 120(4): 945-959, doi: 10.1016/j.foodchem.2009.11.052

Madenci, A.B. (2017). Besinsel lif ve antioksidan maddece zengin bileşenlerin yaş makarnanın bazı kalite özellikleri ve raf ömrü üzerine etkisi. Doktora Tezi, Necmettin Erbakan Üniversitesi Fen Bilimleri Enstitüsü Gida Mühendisliği Anabilim Dalı Doktora Tezi, Konya, Türkiye, 212 s.

Oh, N.H., Seib, P.A., Chung, D.S., Deyoe, C.W. (1985). Noodle III. Effects of processing variables on the quality characterstics of dry noodle. Cereal Chem, 62(6): 437-440.

Özkaya, B., Baumgartner, B., Özkaya, H. (2017). Effects of concentrated and dephytinized wheat bran and rice bran addition on bread properties. $J$ Texture Stud, 49 (1): 84-93, doi: 10.1111/jtxs.12286

Özkaya, H., Kahveci, B., (1990). Tahıl ve Ürünleri Analiz. Yöntemleri, Gıda Teknolojisi Derneği Yayınları, No:14, Ankara.

Pandey, A., Szakacs, G., Soccol, C.R., RodriguezLeon, J.A., Soccol, V.T. (2001). Production, 
purification and properties of microbial phytases. Bioresour Technol, 77(3): 203-214, doi: 10.1016/S0960-8524(00)00139-5

Patel, S. (2015). Cereal bran fortified-functional foods for obesity and diabetes management: Triumphs, hurdles and possibilities. J Funct Foods, 14: 255-269, doi: 10.1016/j.jff.2015.02.010

Rakhesh, N., Fellows, C.M., Sissons, M. (2015). Evaluation of the technological and sensory properties of durum wheat spaghetti enriched with different dietary fibers. J Sci Food Agric, 95: 211, doi: 10.1002/jsfa.6723

Rosa-Sibakov, N., Heiniö, R.L., Cassan, D., Holopainen-Mantila, U., Micard, V., Lantto, R., Sozer, N. (2016). Effect of bioprocessing and fractionation on the structural, textural and sensory properties of gluten-free faba bean pasta. LWT-Food Science and Technology, 67: 27-36, doi: 10.1016/j.lwt.2015.11.032

Servi, S., Özkaya, H., Colakoglu, A.S. (2008). Dephytinization of wheat bran by fermentation with bakers' yeast, incubation with barley malt flour and autoclaving at different $\mathrm{pH}$ levels. $J$ Cereal Sci,48(2): 471-476, doi: 10.1016/j.jcs.2007.10.011

Si, J.Q., Drost-Lustenberger, C. (2002). Enzymes for bread, pasta and noodle products. In: Ensymes in Food Technology, Whitehurst R.J., Law, B.A.,1954 (eds.), Sheffield Academic Press-CRC Press, USA, pp. 19-54.

Sudha, M.L., Ramasarma, P.R., Rao, G.V. (2011). Wheat bran stabilization and its use in the preparation of high-fiber pasta. Food Sci Technol Int, 17:47-53, doi: 10.1177/1082013210368463
Susanna, S., Prabhasankar, P. (2015). Effect of different enzymes on immunogenicity of pasta. Food Agric Immunol, 26(2): 231-247, doi: 10.1080/09540105.2014.893999

Takács, K., Nemedi, E., Marta, D., Gelencsér, É., Kovács, E. (2007). Use of the enzyme transglutaminase for developing gluten-free noodle products from pea flour. Acta Aliment, 36(2): 195-205, doi: 10.1556/AAlim.2007.0008

Takács, K., Gelencsér, É., Kovács, E.T. (2008). Effect of transglutaminase on the quality of wheat-based pasta products. Eur Food Res and Technol, 226(3): 603, doi: 10.1007/s00217-0070604-1

Wang, F., Huang, W., Kim, Y., Liu, R., Tilley, M. (2011). Effects of transglutaminase on the rheological and noodle-making characteristics of oat dough containing vital wheat gluten or egg albumin. $J$ Cereal Sci,54(1): 53-59, doi: 10.1016/j.jcs.2011.02.010

Yeyinli, N. (2006). Makarna kalitesinin belirlenmesinde tekstürel yöntemlerin kullanılabilirliği. Celal Bayar Üniversitesi Fen Bilimleri Enstitüsü Gıda Mühendisliği Anabilim Dalı Yüksek Lisans Tezi, Manisa, Türkiye, 71 s.

Y1lmaz-Tuncel, N., Kaya, E., Karaman, M. (2017). Rice bran substituted Turkish noodles (erişte): Textural, sensorial, and nutritional properties. Cereal Chem, 94(5): 903-908, doi: 10.1094/CCHEM-12-16-0289-R 